\title{
Exploring Selected Game on English for Young Learner's Vocabulary Mastery: The Word Clap Vs Quiz
}

\author{
Desi Nori Sahputri \& Kurniawan Kurniawan \\ Universitas Lancang Kuning, Pekanbaru. Indonesia \\ desputri@gmail.com
}

\author{
Received : 2019-05-11 \\ Revised : 2021-05-19 \\ Accepted : 2019-07-21
}

ARTICLE HISTORY

\section{KEYWORDS}

Vocabulary

Word clap game

Quasi-Experiment

English language

\begin{abstract}
This research was conducted to offer an alternative teaching strategy on raising vocabulary mastery using the Word Clap Game. The purpose of this study was to determine whether there was a difference in the results of the Word Clap Game strategy on EYL's vocabulary mastery of the fifth-grade Narwastu elementary school in Pekanbaru. Indonesia. This Quasi Experiment research involved 60 students with two classes; The experimental class with 29 students (VB class) and the control class with 31 students (VA class). The results of this study highlighted the post-test scores in the experimental class there was seems increased compared with the pre-test scores, this can be seen from the average score of the experimental class post-test that was 76.03 and pre-test 62.75 , the average post-test value in the control class is 74.19, which was lower than the experimental class. Therefore, this study believes that there was no significant difference in students who are taught using the Word Clap Game strategy in mastering vocabulary for students who did not teach using the Word Clap Game strategy both seem effective in raising the EYL vocabulary mastery.
\end{abstract}

\section{Introduction}

English is an international language that is used in many countries over the world containing Indonesia. It is used as a means of communication when Indonesia wants to work together with other countries. English is a second language from junior high school until university, but it is introduced in elementary school as an additional subject in Indonesia. The importance of English in the Indonesian education system is well known. In addition to being a language of science and technology, it is also commonly used as a medium of foreign communication and is one of the United Nations' official languages (Rahman, 2018). As the essential foreign language in Indonesia, English becomes one of the necessary subjects accomplished in an education institute.

In the English language, vocabulary is often viewed as a tool for foreign language. Vocabulary is a crucial aspect of evolving speaking, listening, writing, and reading language skills. Mastering vocabulary means that we recognize all the words in the language which we use. Students who have good vocabulary can make it easier to understand the meaning of the words, and mastering vocabulary is the key to language learning. On the other hand, Richard and Renandya (2002) state that without an extensive vocabulary and strategies for acquiring new vocabulary, learners often achieve less than their potential and may be disheartened from the creative usage of language learning chances about them.

Therefore students must learn vocabulary as a foreign language. Nevertheless, it is not easy for people to master English vocabulary, especially for students. Nursafira (2020) added that many EFL students have struggled to learn vocabulary, making it difficult for them to express themselves or provide knowledge. Based on the interview with Mrs. Hernita Sitanggang, S.Pd, English teacher of SD Narwastu Pekanbaru on 9 April 2019, the phenomena in vocabulary were: First, the students generalizing the meaning of words that they are already familiar with. The second phenomenon, the students should understand the words of vocabulary appropriate to reading, but they cannot connect the words correctly when understanding vocabulary while reading that is following the topic. Third, the student it challenging to remember vocabulary, and also, they have lack motivation to learn, so it is difficult for them to memorize the new vocabulary.

Based on the phenomena above, the researcher covered the problems that happened to the students in teaching and learning vocabulary by using the game. The students need somewhat exciting that makes them relaxed to learns vocabulary. Susilo (2019) said that English language teachers and students in schools may use techniques to make English teaching and learning more natural and straightforward. 
According to Nguyen and Khuat in Fahmiati (2016) states games have been shown to have advantages and effectiveness in learning vocabulary in various ways. First, games transport in lessening and fun for apprentices. Second, games usually include welcoming achievement and retain learners' attention. Agustin (2016), who has researched games, states that one of the games that can improve students' vocabulary mastery is Word Clap Game. Based on her observation, Word Clap Game can be used as a strategy to improve the students' vocabulary.

It is also stated by Ayuningtyas (2016) that word clap game as a medium for teaching English vocabulary since there are several benefits such as; students can improve their vocabulary mastery and try to remember the vocabularies as soon as they clap their hands. According to Babaie (2014), quizzes effectively learn new vocabulary items and retain these learned items in mind over time.

Based on identifying the problem above, the researcher limited the student's vocabulary knowledge by using Word Clap Game toward fifth-grade students' vocabulary at SD Narwastu Pekanbaru. Referring to the above statements, the researcher sees that that formulation of the research can be constructed as "Is there any difference of student's vocabulary who taught using in terms of Word Clap Game between student taught using Quiz on students' vocabulary of the fifth grade at SD Narwastu Pekanbaru?".

Further, it covers finding out the effect of the Word Clap Game on the fifth-grade student's vocabulary of the fifth grade at SD Narwastu Pekanbaru. Finally, related to the explanation above, the researcher conducted experimental research entitled "The Effects of Word Clap Game on Students' Vocabulary at SD Narwastu Pekanbaru".

\section{Discussion}

\subsection{Type of the Research}

This experiment research employs a QuasiExperimental (pre-test and post-test) in BetweenGroup Research where the research compares two or more groups. The researcher conducted experimental treatment activities using Word Clap Game in experimental B class and quiz in experimental A class by giving a pre-test to both groups. The last, the researcher delivers a post-test to both groups.
Table 1. Research Design

\begin{tabular}{cccc}
\hline Class & Pre-Test & Treatment & Post-test \\
\hline $\begin{array}{c}\text { Experimental } \\
\text { A }\end{array}$ & $\mathrm{O}_{1}$ & $\sqrt{ }$ & $\mathrm{O}_{2}$ \\
$\begin{array}{c}\text { Experimental } \\
\text { B }\end{array}$ & $\mathrm{O}_{3}$ & $\sqrt{ }$ & $\mathrm{O}_{4}$ \\
\hline
\end{tabular}

Note:

O1: Pre-test to experiment and control class

O2: Post-test to experiment and control class

$\sqrt{ }$ : Receiving treatment, that is using Word Clap Game and Quiz

\subsection{Population and Sample}

The population was all of the students in the fifth grade of SD Narwastu Pekanbaru academic year $2018 / 2019$. They consisted the total number of the students is 60 .

Table 2. The Population and Sample of the research

\begin{tabular}{cccc}
\hline No & Classes & $\begin{array}{c}\text { Number of } \\
\text { Students }\end{array}$ & Main Score \\
\hline 1 & V A & 31 students & 65.48 \\
2 & V B & 29 students & 62.75 \\
\hline & Total & 60 students &
\end{tabular}

A sample was part of the population being examined at the time of research. Thus, the sample of research should be less than the population. The sample must have the characteristics, which represented all the population being observed in the research. In other words, the sample was a subject of individuals or classes based on the students-based score to see students had the equal ability. After calculating the score, the researcher concluded that students' average score of class VA was 65.48 , while class VB was 62.75. it showed both classes had the equal ability. Then researcher randomly took a sample of research. The researcher took two classes as the sample of this research by using a lottery. Before doing that, the researcher committed the first taken out as an experiment class, and the second was a control class. Those are VA became the experimental $\mathrm{A}$, and $\mathrm{VB}$ becomes the experimental $\mathrm{B}$. 


\subsection{The setting of the research}

The research was conducted in the class VA and VB of SD Narwastu Pekanbaru. It was carried out from Mei 2018 to June 2018. This research a long three weeks in six meetings and the strategy used in the experimental class, the schedule of this research that showed in table 3 .

Table 3. The Schedule of Class Instruction Treatment Class

\begin{tabular}{cccc}
\hline No & Meetings & $\begin{array}{c}\text { Activities } \\
\text { Experimental A }\end{array}$ & $\begin{array}{c}\text { Activities } \\
\text { Experimental B }\end{array}$ \\
\hline 1 & Meeting 1 & Pre-Test & Pre-Test \\
& $(2$ November 2019) & Quiz of & Word Clap \\
2 & Meeting 2 & vocabulary & Game \\
& $(4$ November 2019) & Quiz of & Word Clap \\
3 & Meeting 3 & vocabulary & Game \\
& (6 November 2019) & Quiz of & Word Clap \\
4 & Meeting 4 & vocabulary & Game \\
& (11 November 2019) & Quiz of & Word Clap \\
& (18 November 2019) & vocabulary & Game \\
& Meeting 6 & Post-Test & Post-Test \\
\hline
\end{tabular}

\subsection{The technique of collecting the data}

The instrument of the research used a test. The test was in vocabulary knowledge. The test was constructed in multiple-choice that consist of 20 items, one item score is 5 , and the maximum score is 100.

Table 4. Blue Print Pre-Test and Post-Test

\begin{tabular}{|c|c|c|c|c|c|}
\hline \multicolumn{2}{|c|}{ Pre-Test } & \multirow{2}{*}{$\begin{array}{c}\text { Key } \\
\text { Answer } \\
\text { A, D, B, } \\
\text { A, B }\end{array}$} & \multicolumn{2}{|r|}{ Post-Test } & \multirow{2}{*}{$\begin{array}{l}\text { Key Answer } \\
\text { B,A,A,C,C,A }\end{array}$} \\
\hline Noun & $16,17,18,19,20$ & & Noun & $13,14,16,17,18,20$ & \\
\hline Verb & $1,2,3,4,5$ & $\begin{array}{c}\mathrm{B}, \mathrm{A}, \mathrm{B}, \\
\mathrm{C}, \mathrm{A}\end{array}$ & Verb & $1,2,3,19$ & $\mathrm{~A}, \mathrm{~A}, \mathrm{C}, \mathrm{B}$ \\
\hline Adjective & $11,12,13,14,15$ & $\begin{array}{c}\mathrm{D}, \mathrm{A}, \mathrm{D}, \\
\mathrm{A}, \mathrm{A}\end{array}$ & Adjective & $9,10,11,12,15$ & $\mathrm{~B}, \mathrm{~A}, \mathrm{~B}, \mathrm{~B}, \mathrm{C}$ \\
\hline Preposition & $6,7,8,9,10$ & $\begin{array}{c}\mathrm{B}, \mathrm{A}, \mathrm{A}, \\
\mathrm{C}, \mathrm{B}\end{array}$ & Preposition & $4,5.6,7,8$ & $\mathrm{~B}, \mathrm{C}, \mathrm{A}, \mathrm{C}, \mathrm{A}$ \\
\hline
\end{tabular}

\subsection{The technique of Analyzing the data}

In this research, the researcher collected the data using the test to collect the data differentiated into pre-test and post-test.

The pre-test was used to ensure the experimental A and experimental B classes' equivalency before conducting the treatment. The pre-test was given to the students in experimental A and Experimental B. After giving the pre-test, the researcher was given treatment using Word Clap Game in teaching vocabulary in experimental B and Quiz in teaching vocabulary in experimental A class. The last step is the post-test. A post-test was given for both classes to gain the students' vocabulary score after treatment and determine the Word Clap Game's effectiveness in teaching vocabulary. 


\subsection{The technique of Analyzing the Data}

The data was analyzed statically to determine whether it is statistically significant or not between experimental A and experimental B classes using Word Clap Game and Quiz. It was analyzed using a T-test if the data is regular and homogeneous, and use U-Mann-Whitney-Test if the data is not regular and homogeneous. The result data then calculate to get the average score.

The researcher used the Software Statistical Package for Social Science (SPSS) for windows 22 before the hypothesis test to analyze the pre-test and post-test data. First is normality test distribution data and homogeneity variance data for both classes. Testing normality distribution data in this research used Kolmogorov Smirnov (KS.21) in program SPSS version 22, while Levene Test for testing homogeneity test, the result data calculated the average of the research. The researcher used N Gain between pre-test and post-test. The formula to find out the result of normality test, homogeneity test, and also the average of the score as follow:

\subsubsection{N-Gain}

$\mathrm{N}$-Gain is used to know the proportion of actual again (pre-test and post-test) with maximum gain. The $\mathrm{N}-$ Gain was interpreted by using the criteria achievement $\mathrm{N}$-Gain score. In this research, the $\mathrm{N}$ Gain formula was used to know the student's vocabulary size using Word Clap Game. The formula $\mathrm{N}-$ Gain score as follows:

$$
\begin{array}{r}
\mathrm{N}-\text { Gain }= \\
\mathrm{S}_{\text {post }}-\mathrm{S}_{\text {pre }} \\
\mathrm{S}_{\text {maks }}-\mathrm{S}_{\text {pre }}
\end{array}
$$

Note:

$\mathrm{S}_{\text {post }}$ : Post-test score

$\mathrm{S}_{\text {pre }}$ : Pre-test score

$\mathrm{S}_{\text {maks }}$ : Maximum ideal score

Table 6. The Criteria Achievement N-Gain Score

\begin{tabular}{ll}
\hline Limitation & Category \\
\hline $\mathrm{g}>0,7$ & High \\
$0,3<\mathrm{g}<0,7$ & Middle \\
$\mathrm{g} \leq 0,3$ & Low \\
\hline
\end{tabular}

Meltzer 2002

\subsubsection{T-test}

The T-test is a parametric statistic used to test the hypothesis, a comparative average of two samples when the data are interval or ratio form. The T-test is used when data is regular and homogeneous. To determine the average and homogeneous data, it uses normality and homogeneity test.

\section{a) Normality Test}

A normality test was needed to determine the distribution of data. Normality data are known through the equitable distribution of regression of each value. One of strategy's used to test the normality of data is Kolmogorov Smirnov (KS-21).

$$
\mathrm{KS}=\mathrm{I}|\mathrm{Fn}(\mathrm{yi}-1)-\mathrm{FO}(\mathrm{yi})|
$$

Note

KS: Value of KS

Fn(yi - 1) : Cumulative percentage frequency before $i$.

F0 (yi): Distribution normal of frequency data at i.

According to (Sugiyono 2010:156), calculating the KS value obtained subsequently compares with the KS value table. Suppose the value calculated KS $<$ KS table accepts $\mathrm{H} 0$, then it means a simple regression model of data or multiple regression follows a normal distribution and conversely. If the value calculated KS $>\mathrm{KS}$ table then rejects $\mathrm{H} 0$, it means that a simple regression model of data or multiple regression does not follow a normal distribution.

\section{b) Homogeneity test}

According to (Sugiyono 2010:147), a homogeneity test is performed to determine research data equality. A regression analysis of research data should have a homogeneous distribution of data and method used to test the Levene test.

$$
\mathrm{L}=\frac{(\mathrm{N}-\mathrm{K}) \sum \mathrm{ni}(\bar{v}-\bar{v} \mathrm{k})^{2}}{(\mathrm{~K}-1) \sum(\mathrm{Vij}-\bar{v} \mathrm{k})^{2}}
$$

Note:

L: Levene Value

$\mathrm{X}$ : Residual data Value

I: Residual data mean

$\mathrm{N}$ : Amount of sample

$\mathrm{K}$ : Amount of group

The value of Levene counting obtained is then compared with the Levene table or can also use a significant comparison with alpha value $5 \%$. If the value of Levene count < Levene table or P-value > $5 \%$ of the data, a simple regression or multiple regression has a homogeneous variety. On the contrary, if the Levene > Levene table or P-value < $5 \%$, then data regression simple or multiple regression does not have homogeneous variety. According to Zulkarnain (2010: 187), the hypothesis by T-test formula as below: 


$$
t=\frac{\overline{x_{1}}-\overline{x_{2}}}{\sqrt{\frac{S_{1}^{2}}{n_{1}}+\frac{S_{2}^{2}}{n_{2}}}}
$$

Note:

$t$ : T-test

$\overline{X_{1}}$ : Mean score of treatment class

$\overline{X_{2}}$ : Mean score of the control class

$S_{1}$ 2: Standard Deviation of Treatment class

$S_{2} 2$ : Standard deviation of the control class

$n_{1}$ : Number of the students of the treatment class

$n_{2}$ : Number of the students of the control class

\subsubsection{U Mann - Whitney test}

U-test is used to test the comparative hypothesis of two independent samples when data are ordinal form. If in an observation interval of the form data, it must be changed first into ordinal data. When the data is still shaped interval, we can use a T-test to test. However, if the assumption of the T-test is not matched, then this test can be used. Two formulas are used for testing; both formulas $\mathrm{t}$ are used in the calculation. It is used to determine the price of $\mathrm{U}$, whichever is smaller. $U$ price more minor that are used for testing and comparing with $\mathrm{U}$ table.

According to Sugiyono (2010: 153), the formula as follow:

$$
\begin{aligned}
& \mathrm{U} 1=\mathrm{n} 1 \cdot \mathrm{n} 2+\frac{\mathrm{n} 1(\mathrm{n} 1+1)}{2}-\mathrm{R} 1 \\
& \mathrm{U} 2=\mathrm{n} 1 \cdot \mathrm{n} 2+\frac{\mathrm{n} 2(\mathrm{n} 2+1)}{2}-\mathrm{R} 2
\end{aligned}
$$

Table 7. Descriptive Statistic of Pre-test Score

\begin{tabular}{ccccccc}
\hline & & & \multicolumn{3}{c}{ Test of mastery concept } & \\
\cline { 5 - 6 } Value & Class & $\mathrm{N}$ & Ideal & Minimum & Maximum & Average \\
& & & score & score & score & \\
\hline Pre- & Experimental B & 29 & 100 & 25 & 95 & 62.76 \\
test & Experimental A & 31 & 100 & 30 & 90 & 65.48 \\
\hline
\end{tabular}

$\mathrm{R} 1$ : amount of rank sample 1
Noted:

$\mathrm{n} 1$ : amount of simple 1

$\mathrm{n} 2$ : amount of simple 2

$\mathrm{U} 1$ : amount of level 1

$\mathrm{U} 2$ : amount of level 2

$\mathrm{R} 2$ : amount of rank sample 2

\section{Findings}

This chapter presents the description of data analysis which is findings discussion. These are done answer the formulation of the research;" Is there any difference of student's vocabulary who taught using in terms of Word Clap Game between student taught using quiz on students' vocabulary of the fifth grade at SD Narwastu Pekanbaru?" In this part, the formulation of the research is discussed. The formulation was answered based on the data gotten from a multiple-choice test.

\subsection{The Result of the Research}

\subsubsection{Pre-test}

In the experimental research, students' score of pre-tests needed to be taken into account as the research data. The students did a pre-test before I did the treatment to the experimental group. The purpose of administering the pre-test was to find out the students before the treatment began. As I explained in the previous chapter, the test was multiple choice in vocabulary that should be done by the students in the experimental A and the experimental B group. Moreover, the result of the pre-test can be seen in the table below.
Table 7 above showed that the minimum score on experimental B was 25 and experimental A was 30. The maximum score on experimental $\mathrm{B}$ in the table was 95. It was higher than experimental A for the maximum score that got 90 . Test of mastery concept on pre-test from the average showed experimental B was 62.76 and experimental A was 65.48. It concluded that experimental B knew was lower than experimental A with 65.48 as the average score. The result of the pre-test and post-test of experimental B and experimental A can be seen in the following bar diagram below: 
Diagram 1. Comparison Score Pre-test of Experimental B and Experimental A in Vocabulary

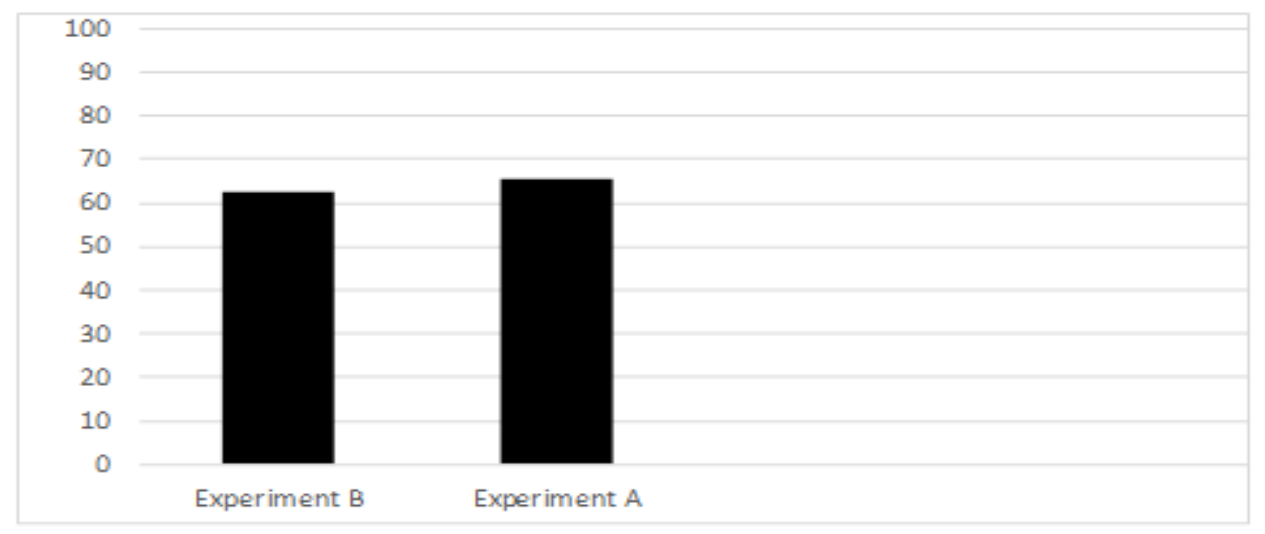

Based on the bar diagram above shows that the average of experimental B lower than experimental A. The mean diagram shown in the experimental $\mathrm{B}$ achieved an average of 62.76 , and the experimental $\mathrm{A}$ class achieved 65.48.

After getting the data comparison of pre-test experimental B and experimental A class, I continued to calculate normality test, homogeneity test, and continuity test of pre-test data using a parametric statistic, namely t-test or U-Mann Whitney test for non-parametric statistics. The T-test can be used if the data is expected and homogenous, while data is not regular or not homogenous, then the data is calculated using non-parametric, namely U-Mann Whitney.

A normality test was done to see the data distributed was normal or not. It was a requirement for establishing the next step in parametric or nonparametric. Here research used Shapiro-Wilk as a formula to get the result of the Normality test. The result of the Normality test of pre-test of both classes can be seen in the following table:

Table 8. Normality Test of Pre-test

\begin{tabular}{ccccc}
\hline Class & $\begin{array}{c}\text { Assymp. Sig. } \\
\text { (2-tailed) }\end{array}$ & $\begin{array}{c}\text { A } \\
\text { (Significant } \\
\text { Level) }\end{array}$ & Hypotheses & Distribution \\
\hline Experimental B & 0.178 & 0.05 & Accept H0 & Normal \\
Experimental A & 0.117 & 0.05 & Accept H0 & Normal
\end{tabular}

Table 8 above shows the normality test done of pre-test on experimental B and experimental A class that the data distribution was expected. Experiment B class in Assymp.Sig. (2-tailed) was 0.178 with a significant level was 0.05 if the data value of Assymp.Sig.(2-tailed) $0.178>0.05$, it meant that the data distribution was normal and experimental A class in Assymp.Sig. (2-tailed) was 0.117 with a significant level was 0.05 if the data value of Assymp.Sig.(2tailed) $0.117>0.05$ meant that the data distribution was normal. (Appendix 6).
The following calculation of the pre-test of both classes was the homogeneity test. It was done to determine the sample's homogeneity, so it was obtained by comparing values based on trimmed mean with the level 0.05 . in analyzing the data, this homogeneity test was calculated by the Levene formula. Based on the result of pre-test to both experimental B and experimental A class got homogeneity test as follows:

Table 9. Homogeneity test of pre-test

\begin{tabular}{ccccc}
\hline Data & Trimmed Mean & $\begin{array}{c}\text { A } \\
\text { (Significant } \\
\text { Level) }\end{array}$ & Hypotheses & Distribution \\
\hline Pre-test & 0.458 & 0.05 & Accept Ho & Homogenous \\
\hline
\end{tabular}


Concerning table 9, homogeneity test of pre-test gained the value of based on trimmed mean that was 0.458 with significant level 0.05 , that was why said that the pre-test on experimental $\mathrm{B}$ and experimental A class were coming from homogenous variance when based on trimmed mean $0.458>0.05$, it meant that pre-test data from both of classes were from homogenous variance.
T-test was subsequent testing because the data distribution of pre-test was normal and homogenous. The test that was considered was Assymp.Sig. (2tailed) that was compared with a significant level of 0.05 when the data value of Assymp.Sig.(2-tailed) < 0.05 , so that the data differ significantly, the result of $\mathrm{T}$-test on pre-test can be seen in the following table:

Table 10. T-test Result of Pre-test

\begin{tabular}{ccccc}
\hline Data & $\begin{array}{c}\text { Assymp.Sig.(2- } \\
\text { tailed) }\end{array}$ & $\begin{array}{c}\text { A } \\
\text { (Significant } \\
\text { Level) }\end{array}$ & Hypotheses & Distribution \\
\hline Pre-test & 0.000 & 0.05 & Accept Ha & $\begin{array}{c}\text { Differ } \\
\text { Significantly }\end{array}$
\end{tabular}

As the table 10 above, the T-test of both classes, experimental B and experimental A class, differed significantly. It occurred since the value of Assymp.Sig. (2-tailed) was 0.000. it means that Assymp.Sig.(2-tailed) $0.000<$ significant level, 0.05. here the researcher concluded that the students' ability of experimental B and experimental A class differed significantly. (Appendix 8).

\subsubsection{Post-test}

Based on the data that had been collected, experimental B and experimental A class were getting the post-test data in the following table:

Table 11. Descriptive Statistic of Post-test Score

\begin{tabular}{ccccccc}
\hline \multirow{2}{*}{ Value } & Class & $\mathbf{N}$ & \multicolumn{3}{c}{ Test of mastery concept } & Average \\
\cline { 3 - 6 } & & & $\begin{array}{c}\text { Ideal } \\
\text { score }\end{array}$ & $\begin{array}{c}\text { Minimum } \\
\text { score }\end{array}$ & $\begin{array}{c}\text { Maximum } \\
\text { score }\end{array}$ & \\
\hline \multirow{2}{*}{ Post-test } & Experimental B & 29 & 100 & 40 & 100 & 76.03 \\
& Experimental A & 31 & 100 & 35 & 100 & 74.19 \\
\hline
\end{tabular}

As table 11 shows, the maximum score, minimum score, and the average score of post-test on experimental B class were getting higher than experimental A class. The minimum score for the experimental B class was 40, while the experimental A class was 35 . The maximum score on the experimental A class was 100. It was lower than the score gained by the experimental B class was 100 .
Moreover, the average post-test for the experimental B class was 76.03, and the experimental A class for the average post-test was 74.19. The table above shows that for a post-test score, the experimental B class was higher than the experimental A class after giving some treatments. The comparison of a post-test score of experimental $B$ and experimental A class can be seen on the bar diagram below:

Diagram 2. Comparison Score Post-test of Experimental B and Experimental A-Class



From the diagram above, it can be concluded that the result of the average post-test in both classes that was the average of experimental B class was 76.03, and the experimental A class was 65.48. the experimental B class was higher than the experimental A class. 
About the post-test data was gained experimental $\mathrm{B}$ and experimental A class. The nest calculation was doing normality test, homogeneity test, those tests were one of qualification for the continuing test. The data had normal and homogenous distribution; it was continued by using a T-test. For the data which was not regular and homogenous, U-Mann Whitney was the subsequent testing after the normality test and homogeneity test wholly done, and the data was not regular or homogenous. It used the non-parametric calculation. In this research, a normality test was done to know the distribution data statistic or nonparametric. The normality test in this research used a formula of Shapiro-Wilk. The result of the normality test of post-test can be seen from the following table;

Table 12. Normality test of Post-test

\begin{tabular}{ccccc}
\hline Class & $\begin{array}{c}\text { Assymp. Sig. } \\
\text { (2-tailed) }\end{array}$ & $\begin{array}{c}\text { A } \\
\text { (Significant } \\
\text { Level) }\end{array}$ & Hypotheses & Distribution \\
\hline Experimental B & 0.030 & 0.05 & Accept Ha & Not Normal \\
Experiemntal A & 0.218 & 0.05 & Accept Ho & Normal \\
\hline
\end{tabular}

In table 12 , the normality test of post-test on experimental B class and experimental A class had not normal distribution. Here, the experimental B class had the column Assimp.Sig.(2-tailed) 0.030, it compared with a significant level of 0.05 . Assimp.Sig.(2-tailed) $0.030<0.05$, it meant that data was not normal. While the experimental A class got Assimp.Sig.(2-tailed) 0.218 with a significant level of 0.05. It was normal since Assimp.Sig.(2-tailed) 0.218 $>0.05$. (Appendix 9)
A homogeneity test is done to know the homogeneity of the sample. If the conclusion shows homogeneous, so could be continued by using a simple parametric statistic, compare value based on trimmed mean with appropriate significant level 0.05. on the analysis of the homogeneity test, it used the Levene test. Based on the result of the post-test gained by both classes, the result of the homogeneity test as follows:

Table 13. Homogeneity test of Post-test

\begin{tabular}{ccccc}
\hline Data & $\begin{array}{c}\text { Trimmed } \\
\text { Mean }\end{array}$ & $\begin{array}{c}\text { A } \\
\text { (Significant } \\
\text { Level) }\end{array}$ & Hypotheses & Distribution \\
\hline Post-test & 0.475 & 0.05 & Accept Ho & Homogenous \\
\hline
\end{tabular}

About the table above, the value of trimmed means was 0.475 with a level significant 0.05 . based on trimmed mean was higher than level significant 0.05 . it could be said post-test data on experimental B, and experimental A class were homogeneous variance because trimmed mean $0.475>0.05$. it meant that homogenous (appendix 11)
U-Mann Whitney test was the next testing because distribution post-test data was not normal, where test continue so-called U-test to know the data differ significantly. Analyzing data on this test, that considered was Assimp.Sig. (2-tailed) that was compared with a significant level of 0.05 when the value of Assimp.Sig.(2-tailed) $<0.05$ it did not differ significant. The following table is the result of posttest data:

Table 14. The Result of U-Mann Whitney Test Post-test

\begin{tabular}{ccccc}
\hline Data & $\begin{array}{c}\text { Assymp.Sig.(2- } \\
\text { tailed) }\end{array}$ & $\begin{array}{c}\text { A } \\
\text { (Significant } \\
\text { Level) }\end{array}$ & Hypotheses & Distribution \\
\hline Post-test & 0.565 & 0.05 & Accept H0 & $\begin{array}{c}\text { Not Differ } \\
\text { Significantly }\end{array}$ \\
\hline
\end{tabular}

Based on the table provided above, it can be concluded that the U-Mann Whitney test of post-test on experimental B and experimental A class were not differ significant. This condition, if the value of Asymp Sig (2-tailed) based on the table $0.565>$ significant level 0.05 . The situation here meant that 
the student's initial abilities are both equal and not differ significant. (Appendix 11).

\section{a) N-Gains}

$\mathrm{N}$-Gain was used to know the effect size of the treatment that was given to the experimental class. The calculation was performed based on the N-Gain formula, then comparing with the criteria of achievement $\mathrm{N}-$ Gain. The result of the N-Gain average value of the experimental class correlated with the criteria of achievement of N-Gain value. The result of $\mathrm{N}-$ Gain can be seen as follows;

Table 15. N-Gain Score of Experimental Research

\begin{tabular}{cccccc}
\hline \multirow{2}{*}{ Group } & \multirow{2}{*}{ N } & \multicolumn{3}{c}{ Test of mastery concept } & \multirow{2}{*}{ Average } \\
\cline { 3 - 5 } & & Ideal score & Minimum score & Maximum score & \\
\hline Experimental B & 29 & 100 & 34 & 100 & \multirow{2}{*}{0.37} \\
Experimental A & 31 & 100 & -25 & 100 & \\
\hline
\end{tabular}

Based on the table provided above, the average of $\mathrm{N}$-Gain was 0.37 , which meant that the significance of strategy used in experimental B class was Middle because the Average of N-Gain was 0.37. in criteria of achievement, N-Gain Score could be said Middle if score $0.3<\mathrm{g}<0.7$, and the average of $\mathrm{N}-$ Gain was 0.37 .

So it was Middle. It can be concluded that there was a positive effect of the implementation of the Word Clap Game in Vocabulary at the fifth grade of SD Narwastu Pekanbaru. (Appendix 12).

\subsection{Discussion}

This research was done in the fifth grade of SD Narwastu Pekanbaru. The research samples were VB as the experimental $\mathrm{B}$ class and $\mathrm{VA}$ as the experimental A class. The determination, which is experimental B and experimental A class, was taken using random. Therefore, based on the result of pretest was done in the experimental B and experimental A class showed that there was no significant difference between the two classes. The pre-test's average result showed that the experimental $\mathrm{B}$ got 74.19 and the experimental A group got 65.48. meanwhile, after giving a treatment to the experimental B class by using Word Clap Game, the experimental B class's average score was higher than the experimental A class by using the quiz. It can be seen from the post-test that had been done been between two classes which the experimental B class got 76.03 and experimental A class 74.19.

The result of Null hypotheses is accepted, an Alternative hypothesis is rejected. The N-Gain of the experimental B and experimental A class showed no positive effect of using Word Clap Game to the students of experimental B class and experimental A by using quiz on their ability on vocabulary related to the topic was given. The result of $\mathrm{N}$-Gain of the experimental B class was 0.37. it was correlated with the N-gain criteria of Meltzer. N-Gain's high criteria if the average $\mathrm{N}$-Gain $>0.7$, category medium if the average $\mathrm{N}$-Gain $>0.3$, and category low if $\mathrm{N}$-Gain $\mathrm{g}<0.3$. As clarified previously, there was no positive effect using Word Clap Game and Quiz strategy on students' vocabulary at the fifth grade at SD Narwastu Pekanbaru, where this strategy helped the students learn vocabulary correctly.

\section{Conclusion}

This research aims to identify whether the students who are taught Using the Word Clap Game in vocabulary had a difference in mastering the vocabulary. The students who are taught by using quiz of the strategy and the formulation: "Do the students at the fifth grade of SD Narwastu Pekanbaru taught vocabulary by using Word Clap Game achieve better than the students who are taught by using Quiz?". It has been answered. No, they do not. Word Clap Game and Quiz do not affect students' vocabulary at SD Narwastu Pekanbaru. The results supported the results: There was no significant difference in the students' vocabulary between pro-test and post-test of experimental A and experimental B. It meant that there was no significant difference in the students' vocabulary before and after implementing the Word Clap Game and Quiz at the fifth grade of SD Narwastu Pekanbaru. Furthermore, there was no significant difference in the students' vocabulary between experimental B taught using Word Clap Game, then experimental A taught using a quiz.

\section{References}

Abbas, M. F. F. (2014). APPLYING WORD CHAIN GAME TO IMPROVE
STUDENTS'VOCABULARY
ELT-Lectura, 1(1).

Akdogan, E. (2017). Developing vocabulary in game activities and game materials. Journal of Teaching and Education, 7(1), 31-66.

Alizadeh, I. (2016). Vocabulary teaching techniques: A Review of common practices. International journal of research in English education, 1(1), 22-30.

Alqahtani, M. (2015). The importance of vocabulary in language learning and how to be taught. International journal of teaching and education, 3(3), 21-34. 
Babaie, Z., \& Nordad, N. (2014). The effect of quiz and oral questioning on vocabulary learning and retention of EFL learners. International Journal of Language, Literature and Humanities, 2(5), 253-268.

Cambridge Dictionary. 2019. Quiz. Retrieved from: https://dictionary.cambridge.org/dictionary/eng $\underline{\text { lish/quiz }}$

Case, Alex. (2009, April). Variations on clap clap clap game. Retrieved from https://www.tefl.net/elt/ideas/games/clap-clapclap-game/

Collins Dictionary. Quiz. 2019. Retrieved from https://www.collinsdictionary.com/dictionary/e nglish/quiz

Creswell John, W. (2012). Planning, Conducting, and Evaluating Quantitative and Qualitative Research. Lincoln: University of Nebraska Daulat Purnama.

Fahmiati, N. (2016). Improving students' vocabulary achievement trough word games (a classroom action research at the fifth grade of Tarbiyatul Islamiyah Islamic elementary school Lengkong Batangan Pati in the academic year of 2015/2016) (Doctoral dissertation, UIN Walisongo).

Klimova, B. F. (2015). Games in the Teaching of English. Procedia-Social and Behavioral Sciences, 191, 1157-1160.

Kupečková, L. (2010). Game like activities (Doctoral dissertation, Masarykova univerzita, Pedagogická fakulta).

Mousavi, S. A. (Ed.). (1999). A dictionary of language testing. Rahmana Publications.

Nichols, C. N. (2007). The effects of three methods of introducing vocabulary to elementary students: Traditional, friendly definitions, and parsing (Doctoral dissertation, University of Pittsburgh).

Nursafira, M. S. (2020). TED Talks in EFL Context: An Alternative Way for Teaching and Improving Student's Speaking Skills. ELSYA: Journal of English Language Studies, 2(2), 4347.

Pavlu, I. (2009). Testing Vocabulary. New Jersey: Masaryk University Brno.

Rahman, F. (2018). The Constraints of Foreign Learners in Reading English Literary Works: A Case Study at Hasanuddin University. Journal of Arts and Humanities, 7(2), 01-12.

Richards, J. C., Richards, J. C., \& Renandya, W. A. (Eds.). (2002). Methodology in language teaching: An anthology of current practice. Cambridge university press.
Setiawan, Budi. (2010). Improving the Students' Vocabulary Mastery Through Direct Instruction. Unpublished Thesis. Sebelas Maret University

Sugiyono. 2010.Metode Penelitian Kualitatif kuantitatif dan R\&D. Bandung: CV. Alfabeta

Susanti, P. T. (2017). The Effect of Using Word Clap Game on The Vocabulary Mastery of The Fifth Grade Students at SD Negeri 1 Banjar Jawa in Academic Years of 2017/2018. Journal of Psychology and Instructions, 1(3), 162-169.

Susilo, N. (2019). Kahoot Apps in ELT context: An alternative learning strategy. ELSYA: Journal of English Language Studies, 1(1), 11-15.

Thornbury, S. (2002). How to Teach Vocabulary. Series Editor: Jermy Harmer.

Verhoeven, L., \& Perfetti, C. A. (2011). Introduction to this special issue: Vocabulary growth and reading skill. Scientific Studies of Reading, 15(1), 1-7.

Wikipedia. 2020. Quiz. Retrieved from: https://en.wikipedia.org/wiki/Quiz

Yudantoro, E. (2014). Pintar dan Juara Bahasa Inggris SMA. PandaMedia. 